\title{
Data on the bumblebee assemblages (Apidae: Bombus spp.) lives in lands under agri-environment commitment
}

\author{
Dóra Arnóczkyné Jakab - Antal Nagy \\ University of Debrecen, Institute of Plant Protection, 4032 Debrecen, Böszörményi út 138. \\ jakidori6@gmail.com
}

\section{SUMMARY}

\begin{abstract}
The goal of agri-environmental schemes (AES) and greening programs are protecting and increasing biodiversity in agricultural lands. The evaluation of effectiveness of AES needs further investigations. For the purpose of investigations, species and species groups should be selected which can indicate the effects of changes in landscape use on biodiversity. Bumblebees are good indicators for this purpose.

The role of bumblebees in pollination is well studied but in the case of different crops, much less detailed data are available. In 2018 , bumblebee assemblages of 44 sites belonged to 8 different agricultural and semi-natural habitat types were studied in the surroundings of Sajószöged, Tiszaújváros and Derecske.

This study provides new distribution data of 8 bumblebee species in three $10 \times 10 \mathrm{~km}$ UTM cells covering the sampling area. According to our results, the alfalfa and red clover fields and semi-natural grasslands has more species rich and abundant bumblebee assemblages than different crop fields (sunflower, oilseed radish and vegetable morrow) and can help protect bumblebee assemblages of agricultural lands. Based on the collected distribution and abundance data, the role of the bumblebees in pollination of the studied crops should be re-evaluated.
\end{abstract}

Keywords: agri-environment schemes (AES), greening, ecological focus area (EFA), Bombus, bumblebee

\section{INTRODUCTION}

In Europe, the agri-environmental schemes (AES) have been introduced in the beginning of the 90's. Governments provide area-based payment and they have to make use of various practices that reduce the negative impacts of extensive farming systems on the environment and climate and increase biodiversity in agricultural lands (Badenhausser and Cordeau, 2012). The greening programs are important parts of the agrienvironmental schemes since the crop diversification, the use of permanent grassland and ecological focus areas are effective way of increasing biodiversity in agricultural lands (Benton et al., 2003).

Greening supports action to adopt and maintain farming practices that help meet environmental and climate goals (Donald et al., 2002; Kovács, 2017; Ovenden et al., 1998). Mainly the urbanisation and agricultural intensification are responsible for biodiversity loss, environmental or landscape changing and environment degradation (Firbank et al., 2008; Gaston, 2005; Luck et al., 2004). Although the role of „green infrastructure" in the biodiversity conservation and human welfare is increasingly well-known, for the evaluation of the effectiveness of agri-environmental schemes, many investigations should be made (Kleijn and Sutherland, 2003; Gordon et al., 2009; Jorgensen and Gobster, 2010). This is especially necessary in the Central and Middle European countries because in this region the biodiversity is higher, while the agriculture is less intensive then in West European region (Donald et al., 2002; EEA, 2003; Jeanneret et al., 2003).

For investigations species and species groups should be selected which can indicate the effects of changes in landscape use on biodiversity (McGeoch, 1998; Wiens, 1989). Pollinators, for example bumblebees are good indicators of the effectiveness of agri-environmental schemes (Sepp et al., 2004,
Osborne et al., 1999). Bumblebees are one of the main pollinators of crops and wild flowers in the northern temperate zone (Knight et al., 2005). Pollination of more than $80 \%$ of European plant species belongs to insect pollinators, thus their role in the ecosystems is evident (Williems, 1994). This ecosystem service generates income of 5 billion Euros per year for European farmers, while in worldwide this mean 150 billion Euros per year (Gallai et al., 2009). Although the abundance of pollinators especially of bees recently decreased (Buchmann and Nabhan, 1996; Westrich, 1996; Williams, 1982; 1986). For wild bees the agricultural intensification is extremely dangerous (Williams, 1989). In Europe, areas of many bumblebee species shrank (Donath, 1985; Williams, 1986; Rasmont, 1988), which takes effect on success of pollination (Corbet et al., 1991; Allen-Wardell et al., 1998).

Although there have been many studies on bumblebees, but the agricultural and especially the arable lands are mainly under investigated (Goulson, 2003), and we have much less data on effects of greening programs on bumblebee species and assemblages.

To compensate the lack of information, we study and compare the bumblebee fauna and assemblages of different crops, hedges and semi-natural grasslands.

\section{MATERIALS AND METHODS}

Our samplings were carried out between June and August of 2018 in 44 sampling sites. The studied habitats were sunflower, oilseed radish, vegetable marrow, alfalfa and red clover fields, alfalfa hedging ( 6 $\mathrm{m}$ wide margin cropped with pulses and grasses according to requirement of AES (Agócs et al., 2015) and semi-natural grasslands (hayfields with Vicia cracca, Lotus corniculatus, Trifolium repens, $T$. 
pratense and Plantago lanceolate and dike slopes with Medicago sativa, L. corniculatus, T. pratense).

Bumblebees were sampled with visual detection along a linear transect during 10 minutes per sample. The number of bumblebees by species and the visited plant species were detected (The host plant preference of different bumblebee species will be analysed further on).

Specimens of Bombus terrestris and B. lucorum (National Biodiversity Data Centre, 2012), as well as specimens of $B$. hortorum and B. ruderatus (Williams and Hernandez, 2000) cannot be identified in species level thus we regard them as species pairs. During the analysis the total, the minimum and maximum and mean species number of different habitat types were determined and calculated and to compare the qualitative composition of assemblages Whittaker index $\left(\mathrm{S} / \mathrm{S}_{\text {mean }}\right)$ was calculated.

We collect faunistical data for EU00, EU01 and ET44 10 $\times 10 \mathrm{~km}$ UTM cells (Figure 1 ). The evaluation of these data based on the work of Sárospataki and coworkers (2003), who made UTM based distribution data base of the Hungarian bumblebee fauna.

Figure 1: Location of sampling sites $(n=44)$ on the $10 \times 10 \mathrm{~km}$ UTM map of Hungary

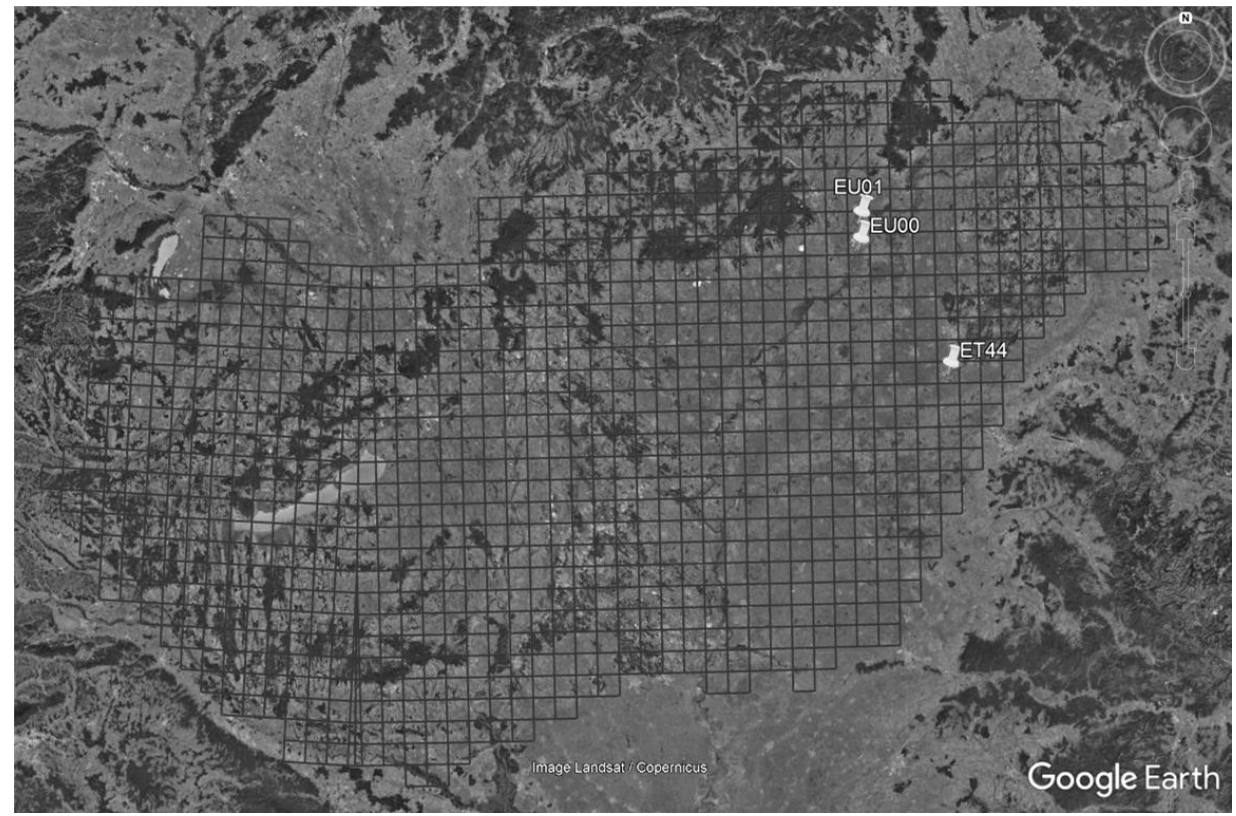

Source: Google Earth

\section{RESULTS AND DISCUSSION}

\section{Bumblebee assemblages}

During the sampling period 269 specimen of 8 bumblebee species were detected. The sampled species were: Bombus terrestris/lucorum, B. lapidarius, $B$. ruderarius, $B$. hortorum/ruderatus, B. sylvarum, $B$. pascuorum, B. humilis, B. hypnorum).

We found at least 2 bumblebee species in all the studied habitat types except the vegetable marrow fields. The explanation of the latter result need further investigations. The total species number was highest in the grassland of dike slopes, where many flowering plants could be found, and the surroundings of these habitats were also more diverse than in case of other studied habitat types.

B. terrestris/lucorum and B. lapidarius occurred almost in all habitat types (except vegetable marrow). The most abundant species was B. lapidaries with 156 individuals in total. It was followed by $B$. terrestris/lucorum (52 individuals), while only $3 \mathrm{~B}$. ruderarius and 1-1 individual of $B$. humilis and $B$. hypnorum were sampled (Table 1).

The mean and the maximum species number were also highest in the dike slopes, while the less species rich habitats were the vegetable marrow and oilseed radish fields. In five of the seven habitats occupied by bumblebees the total number of species and maximum number of species were equal, thus there was at least one sampling site in each type where all species of the given habitat were occurred. One of the dike slope sampling sites was the most species rich site with 6 bumblebee species. Species richness of red clover fields, hayfields and sunflower were equal, but the mean species number of sampling sites were much less in the sunflower fields. The species richness of alfalfa and red clover fields and hayfields were mainly equal (between 2.5 and 2.8), and they had relatively species rich bumblebee habitats. Considering mean species number, the oilseed radish and sunflower fields (sampling sites) were the less species rich habitats $(0.6$ and 1.8). 
Total number of sampled individuals $(\mathrm{N})$ and distribution of the sampled 8 bumblebee species in the different studied habitat types $\mathrm{x}=$ occurrence

\begin{tabular}{|c|c|c|c|c|c|c|c|c|c|}
\hline & sunflower & $\begin{array}{c}\text { oilseed } \\
\text { radish }\end{array}$ & $\begin{array}{c}\text { vegetable } \\
\text { marrow }\end{array}$ & $\begin{array}{c}\text { alfalfa } \\
\text { hedging }\end{array}$ & alfalfa & $\begin{array}{c}\text { red } \\
\text { clover }\end{array}$ & hayfields & $\begin{array}{l}\text { dike } \\
\text { slope }\end{array}$ & $\mathrm{N}$ \\
\hline Bombus terrestris/lucorum & $\mathrm{x}$ & $\mathrm{x}$ & & $\mathrm{x}$ & $\mathrm{x}$ & $\mathrm{x}$ & $\mathrm{x}$ & $\mathrm{x}$ & 52 \\
\hline Bombus lapidarius & $\mathrm{x}$ & $\mathrm{x}$ & & $\mathrm{x}$ & $\mathrm{x}$ & $\mathrm{x}$ & $\mathrm{x}$ & $\mathrm{x}$ & 156 \\
\hline Bombus ruderarius & & & & & $\mathrm{x}$ & & & $\mathrm{x}$ & 3 \\
\hline Bombus hortorum/ruderatus & & & & & $\mathrm{x}$ & $\mathrm{x}$ & & $\mathrm{x}$ & 10 \\
\hline Bombus sylvarum & $\mathrm{x}$ & & & $\mathrm{x}$ & & & $\mathrm{x}$ & $\mathrm{x}$ & 32 \\
\hline Bombus pascuorum & & & & & $\mathrm{x}$ & & $\mathrm{x}$ & $\mathrm{x}$ & 14 \\
\hline Bombus humilis & & & & & & $\mathrm{x}$ & & & 1 \\
\hline Bombus hypnorum & $\mathrm{x}$ & & & & & & & & 1 \\
\hline
\end{tabular}

According to Whittaker index the quantitative composition of bumblebee assemblages of different habitats showed differences. The total value of index was higher than each value of different habitats. The heterogeneity of sampling sites was highest in oilseed radish and sunflower fields (Table 2).

The mean bumblebee abundance was highest in dike slopes while in the alfalfa hedging and oilseed radish field were especially bare considering bumblebee abundances.

Characteristic data of bumblebee assemblages of different studied habitat types

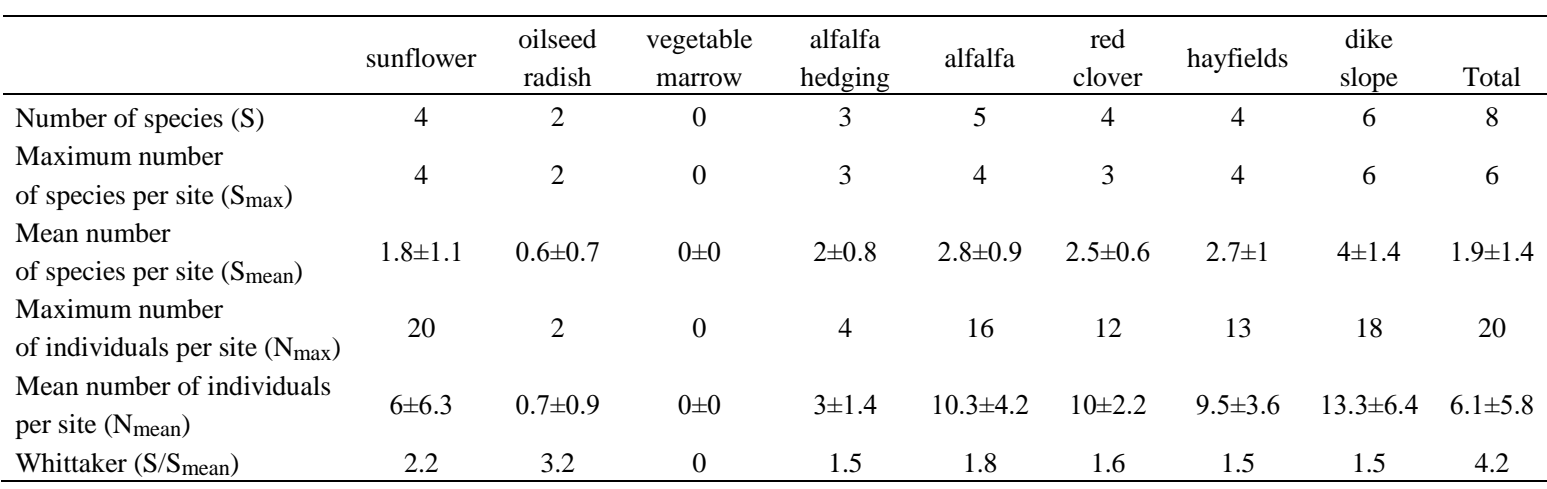

\section{Distribution data}

We compare the collected bumblebee data in the EU00, EU01 and ET44 10×10 km UTM cells with distribution data published by Sárospataki et al. (2003). Considering EU00 cell we collected $B$. terrestris/lucorum, B. lapidarius, $B$. ruderarius, $B$. hortorum/ruderatus, B. sylvarum, B. pascuorum, and B. hypnorum data, in case of EU01 cell Bombus terrestris/lucorum, B. lapidarius, B. ruderarius, $B$. hortorum/ruderatus, B. sylvarum, B. pascuorum and B. humilis, while in case of ET44 cell Bombus terrestris/lucorum és a $B$. lapidarius data were collected. We provided new distribution data for 6 species in the EU00 cell, for 7 species for the EU01 cell and for 1 species in the ET44 cell. Distribution data base of the three studied UTM cells improved with 14 new data record of 8 bumblebee species (Table 3).

New distribution data records of EU00, EU01 and ET44 $10 \times 10 \mathrm{~km}$ UTM cells by species

\begin{tabular}{lccc}
\hline & EU00 & EU01 & ET44 \\
\hline B. terrestris/lucorum & & $\mathrm{x}$ & $\mathrm{x}$ \\
B. lapidarius & $\mathrm{x}$ & $\mathrm{x}$ & $\mathrm{x}$ \\
B. ruderarius & $\mathrm{x}$ & $\mathrm{x}$ & $\mathrm{x}$ \\
B. hortorum/ruderatus & $\mathrm{x}$ & $\mathrm{x}$ & $\mathrm{x}$ \\
B. sylvarum & $\mathrm{x}$ & $\mathrm{x}$ & \\
B. pascuorum & & $\mathrm{x}$ & \\
B. humilis & & & \\
B. hypnorum & &
\end{tabular}




\section{CONCLUSION}

During this study, different agricultural and seminatural habitats were sampled to collect quantitative and qualitative data on bumblebee assemblages. Samplings were made in summer of 2018 in 44 sampling sites of sunflower, oilseed radish, vegetable marrow, alfalfa and red clover fields, alfalfa hedging and semi-natural grasslands of hayfields and dike slopes.

The most species rich and abundant bumblebee assemblages were found in grasslands of dike slopes. These habitats were most mosaic and flower rich and even their surroundings were also more divers than in case of the other sampled habitat types.

Hayfields, alfalfa and red clover fields were also suitable for bumblebees they showed also relatively high mean species numbers and abundances. The alfalfa hedging was relatively poor in bumblebees but were most suitable than the studied crop fields (oilseed radish, sunflower, and vegetable marrow). Although based on the literature (Goulson, 2003) the oilseed radish and vegetable marrow, included by greening programs, are suitable habitats for bumblebees. In this case we found opposite results, thus this topic needs further investigations. Sunflower fields showed high variability considering both species number and abundances.

According to our results alfalfa and red clover, which are involved in greening programs as nitrogen fixing plant and secondary crops with ecological impact, can help protect of bumblebee species and assemblages of agricultural landscapes. The alfalfa hedging provides less source for bumblebees, but it also can increase their abundance and species number. Based on our results the role of bumblebee pollination in case of the studied crops should be re-evaluated.

Beyond that we provide new distribution data of 8 bumblebee species in three $10 \times 10 \mathrm{~km}$ UTM cells of the Hungarian Plane cover surroundings of Tiszaújváros, Sajószöged and Derecske.

\section{REFERENCES}

Agócs, B.-Galambos, A.-Hegymegi, P.-Kary, L.-Keszthelyi, K.Kiss, A.-Kovács, V.-Néráth, M.-Rezneki, R.-Sztahura, E.Tóth, P.-Várszegi, G. (2015): Agrár-környezetgazdálkodás. Sztahura E.-Rezneki R.(Eds.) Nemzeti Agrárgazdasági Kamara, Budapest. 72 p. (ISBN 9786155307195)

Allen-Wardell, G.-Bernhardt, P.-Bitner, R.-Burquez, A.Buchmann, S.-Cane, J.-Allen Cox, P.-Dalton, V.-Feinsinger, P.-Ingram, M.-Inouye, D.-Jones, C. E.-Kennedy, K.-Kevan, P.-Koopowitz, H.-Medellin, R.-Medillin-Morales, S.-Nabhan, G. P. (1998): The potential consequences of pollinator declines on the conservation of biodiversity and stability of food crop yields. Conservation Biology. 12: 8-17.

Badenhausser, I.-Cordeau, S. (2012): Sown grassstrip-A stable habitat for grasshoppers (Orthoptera: Acrididae) in dynamic agricultural landscapes. Agriculture, Ecosystems and Environment. 159: 105-111.

Benton, T.-Vickery, J.-Wilson, J. D. (2003): Farmland biodiversity: is habitat heterogeneity the key? Trends in Ecology and Evolution. 18: 182-188.

Buchmann, S. L.-Nabhan, G. P. (1996): The forgotten pollinators Island Press, Washington DC. 292 p. (ISBN 9781559633536)

Corbet, S. A.-Williams, I. H.-Osborne, J. L. (1991): Bees and the pollination of crops and wildflowers in the European Community. Bee World. 72: 47-59.

Goulson, D. (2003): Bumblebees: Their Behaviour and Ecology. Oxford University Press, New York. 235 p. (ISBN 0198526075)

Donald, P. F.-Pisano, G.-Rayment, M. D.-Pain, D. J. (2002): The common agricultural policy, EU enlargement and the conservation of Europe's farmland birds. Agriculture, Ecosystems and Environment. 89: 167-182.

Donath, H. (1985): Gefährdung und Schutz unserer Hummeln. Naturschutzarbeitin Berlin und Brandenburg. 21: 1-5.

EEA. (2003): Europe's environment the third assessment. Environmental assessment report 10. Copenhagen: European Environment Agency.

Firbank, L. G.-Petit, S.-Smart, S.-Blain, A.-Fuller, R. J. (2008): Assessing the impacts of agricultural intensification on biodiversity: a British perspective. Philosophical Transactions Royal Society B. 363: 777-787.

Gallai, N.-Salles, J. M.-Vaissiére, B. E. (2009): Economic valuation of the vulnerability of world agriculture confronted with pollinator decline. Ecological economics. 68: 810-821.

Gaston, K. J. (2005): Biodiversity and extinction: Species and people. Progress in Physical Geography. 29: 239-247.

Gordon, A.-Simondson, D.-White, M.-Moilanen, A.-Bekessy, S. (2009): Integrating conservation planning and landuse planning in urban landscapes. Landscape and Urban Planning. 91: 183194.

http://www.biodiversityireland.ie/wordpress/wp-content/uploads/B.lucorum-and-B.-terrestris 1.pdf

Jeanneret, P.- Schupbach, B.-Luka, H. (2003): Quantifying the impact of landscape and habitat features on biodiversity in cultivated landscapes. Agriculture, Ecosystems and Environment. 98: 311-320.

Jorgensen, A.-Gobster, P. (2010): Shades of green: Measuring the ecology of urban greenspace in the context of human well-being. Nature and Culture. 5: 338-363.

Kleijn, D.-Sutherland, W. J. (2003): How effective are European agri-environment schemes in conserving and promoting biodiversity? Journal of Applied Ecology. 40: 947-969.

Knight, M. E.-Martin, A.P.-Bishop, S.-Osborne, J. L.-Hale, R. J.Sanderson, R. A.-Goulson, D. (2005): An interspecific comparison of foraging range and nest density of four bumblebee (Bombus) species. Molecular Ecology. 14: 1811-1820.

Kovács, M.-Kránitz, L.-Madarász, I.-Magyari, R.-Palakovics, Sz.Pethő, J.-Rezneki, R.-Szabó, E.-Szerletics, Á.-Sztahura, E.Tengerdi, G.-Zsemle, V. (2017): Zöldítés. Nemzeti Agrárgazdasági Kamara, Budapest. 65 p. (ISBN 9786155307294)

Luck, G. W.-Ricketts, T. H.-Daily, G. C.-Imhoff, M. (2004): Alleviating spatial conflict between people and biodiversity. Proceedings of the National Academy of Sciences. 101: 182186. 
McGeoch, M. (1998): The selection, testing and application of terrestrial insects as bioindicators. Biological Reviews. 73: 181201.

National Biodiversity Data Centre (Documenting Ireland's Wildlife) (2012): Distinguishing between B. lucorum and B. terrestris. 30 p.

Osborne, J. L.-Clark, S. J.-Morris, R. J.-Williams, I. H.-Riley, J. R.Smith, A. D.-Reynolds, D. R.-Edwards, A. S. (1999): A landscape-scalestudy of bumblebee foraging range and constancy, using harmonic radar. Applied Ecology. 36: 519-533.

Ovenden, G. N.-Swash, A. R. H.-Smallshire, D. (1998): Agrienvironment schemes and their contribution to the conservation of biodiversity in England. Journal of Applied Ecology. 35: 955960.

Rasmont, P. (1988): Monographieé cologique et zoogéographique des bourdons de France et de Belgique (Hymenoptera. Apidae, Bombinae). PhD Thesis. Faculté des Science Agronomique de l'Etat, Gembloux, Belgium.

Sárospataki, M-Novák, J.-Molnár, V. (2003): Hazai poszméh- és álposzméhfajok (Hymenoptera: Apidae, Bombus és Psithyrus) UTM-térképezése és az adatok természetvédelmi felhasználhatósága. Állattani Közlemények. 88. 1: 85-108.

Sepp, K.-Mikk, M.-Mand, M.-Truu, J. (2004): Bumblebee communities as an indicator for landscape monitoring in the agrienvironmental programme. Landscape Urban Plan. 67: 173-183.
Westrich, P. (1996): Habitat requirements of central European bees and the problems of partial habitats. In.: Matheson, A.Buchmann, I. H.-O'Toole, C.-Westrich, P.-Williems, I. H. (Eds.): The Conservation of Bees. Academic Press, London. 216.

Wiens, J. A. (1989): Spatial scaling in ecology. Functional Ecology. 3: 385-397.

Williams, I. H. (1994): The dependence of crop production with in the European Union on pollination by honeybees. Agricultural Zoology Reviews. 6: 229-257.

Williams, P.-Hernandez, L. (2000): Distinguishing females of the bumble bees Bombus ruderatus (F.) from Bombus hortorum (L.) in Britain: a preliminary application of quantitative techniques. UK Biodiversity Action Plan, Natural History Museum, London. $25 \mathrm{p}$.

Williams, P. H. (1982): The distribution and decline of British bumblebees (Bombus Latr.). Journal of Apicultural Research. 21: 236-245.

Williams, P. H. (1986): Environmental change and the distributions of British bumblebees (Bombus Latr.). Bee World. 67: 50-61.

Williams, P. H. (1989): Bumblebees - and their decline in Britain. Lecture to the Central Association of Bee-Keepers, April 1988. Central Association of Beekeepers, London, UK 
